\title{
Oral malignant melanoma: a rarity!
}

\author{
Satya Ranjan Misra, ${ }^{1}$ Ujjaval Ramanupam Tripathy, ${ }_{1}^{1}$ Rupsa Das, ${ }^{1}$ Neeta Mohanty ${ }^{2}$
}

${ }^{1}$ Oral Medicine \& Radiology, Institute of Dental Sciences, Siksha 'O' Anusandhan University, Bhubaneswar, Odisha, India

${ }^{2}$ Oral Maxillofacial Pathology \& Microbiology, Institute of Dental Sciences, Siksha 'O' Anusandhan University, Bhubaneswar, Odisha, India

\section{Correspondence to} Professor Neeta Mohanty; neetamohanty@soa.ac.in

Accepted 28 September 2021

\section{Check for updates}

(c) BMJ Publishing Group Limited 2021. No commercial re-use. See rights and permissions. Published by BMJ.

\begin{tabular}{|l|}
\hline To cite: Misra SR, \\
Tripathy UR, Das R, et al. BMJ \\
Case Rep 2021;14:e246045. \\
doi:10.1136/bcr-2021- \\
246045 \\
\hline
\end{tabular}

\section{DESCRIPTION}

Malignant melanoma (MM) of the oral cavity is an exceedingly rare malignancy of melanocytic origin, presenting as a blackish-brown patch with colour variation within the patch. It accounts for only $1.6 \%$ of all head and neck malignancies and $0.2 \%-8 \%$ of all MMs. ${ }^{1}$ The significance lies in early detection of the lesion because $\mathrm{MM}$ has a poor prognosis, and oral MMs are worse in this regard compared with those on the skin. About a third of all oral MMs are seen on the palate with a definite male gender predilection. They can arise from naevus or pigmented macules or de novo like in this case. Clinical appearance is generally an irregular asymmetric patch $>6 \mathrm{~mm}$ in size with colour variation and a raised rough surface with a history of constant growth. Oral MM has been classified pigmented or non-pigmented and nodular, macular or mixed depending on the clinical appearance. Regional lymphnode metastasis and distant metastasis to the bone, lungs and liver have also been reported in advanced cases. ${ }^{2}$ Physiologic pigmentation, melanotic macule, smoker's melanosis, drug-induced melanosis, melanocytic naevus and pigmentation due to systemic causes like Addison's disease, Peutz-Jeghers syndrome, etc may be considered in the differential diagnosis. ${ }^{3}$ Histologically atypical melanocytes, with hyperchromatism and nuclear pleomorphism in the junction of the epithelium and connective tissue together with immunohistochemical markers positive for S-100, HMB-45 are considered confirmatory for the diagnosis of MM. ${ }^{12}$ Radical excision with disease-free margins is the mainstay of treatment in MM with recurrence in about $20 \%$ of cases.

A 60-year-old manreported with black spots in the right side of the palate. History revealed that the patch appeared on the palate a month back which steadily increased in size but was asymptomatic. On physical examination, an irregular black patch was seen in the left side of the posterior maxillary alveolus in relation to 1517 region (figure 1A) involving the alveolar mucosa buccally (figure 1B) and the hard palate (figure 1C). The lesion was 3 $\mathrm{cm} \times 1.5 \mathrm{~cm}$ in size, black in colour interspersed with shades of grey. The borders were irregular but well-defined, surface smooth and it was rough to touch, unscrapable, non-tender on palpation. A provisional diagnosis of MM was made and the patient was subjected to haematologic, radiologic and histopathologic investigations.

Panoramic radiograph revealed haziness in the right maxillary antrum with the obliteration of the outline of the antral floor (figure 2A). A focal nodular-enhancing soft tissue lesion was observed in the right palate/ gingival sulcus involving the inner alveolar process of maxillary molars with

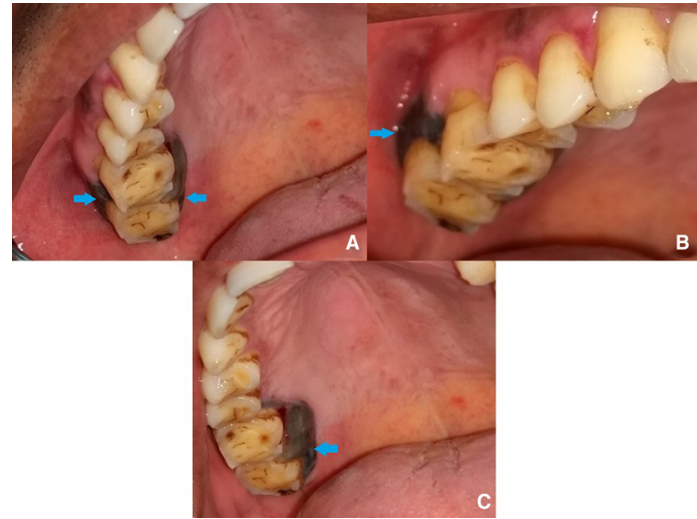

Figure 1 Irregular brownish-black patch present on the left side of the (A) maxillary alveolus extending both (B) buccally $(C)$ and palatally in relation to molar teeth.

thickening of the maxillary antral lining mucosa on contrast-enhanced CT (figure 2B). Focal nodular hyperintensity mass seen on both $\mathrm{T} 1$ and $\mathrm{T} 2$ images extending into the right palate/ gingival sulcus and involving the inner alveolar process of maxillary molars with thickening of the maxillary antral lining mucosa on MRIs (figure 2C).

Following biopsy, the H\&E-stained section revealed proliferation of atypical melanocytes in

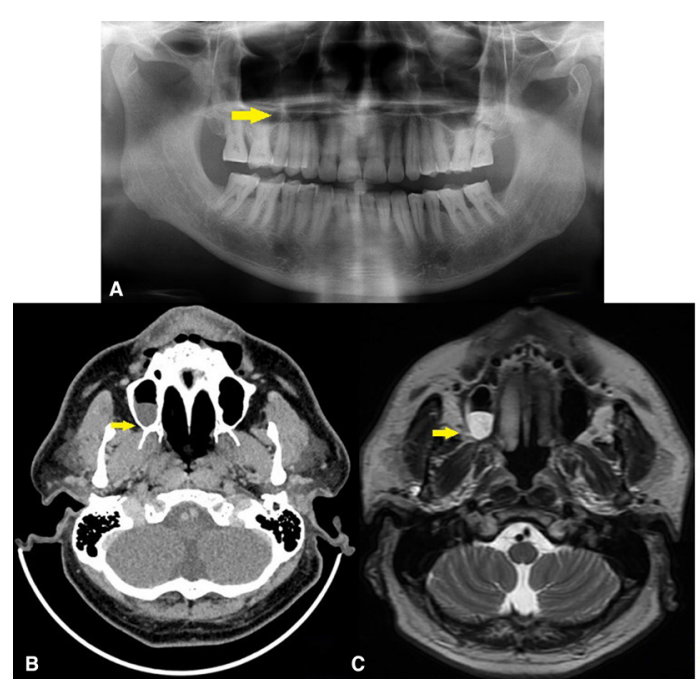

Figure 2 (A) Panoramic radiograph showing haziness in the right maxillary antrum with obliteration of the antral floor. (B) Contrast-enhanced CT showing a focal nodularenhancing soft tissue lesion in the right palate/ gingival sulcus involving the inner alveolar process of maxillary molars with thickening of the maxillary antral lining mucosa. (C) MRI showing focal nodular hyperintensity mass on axial section in the alveolar process of maxillary molars with thickening of the maxillary antral lining mucosa. 


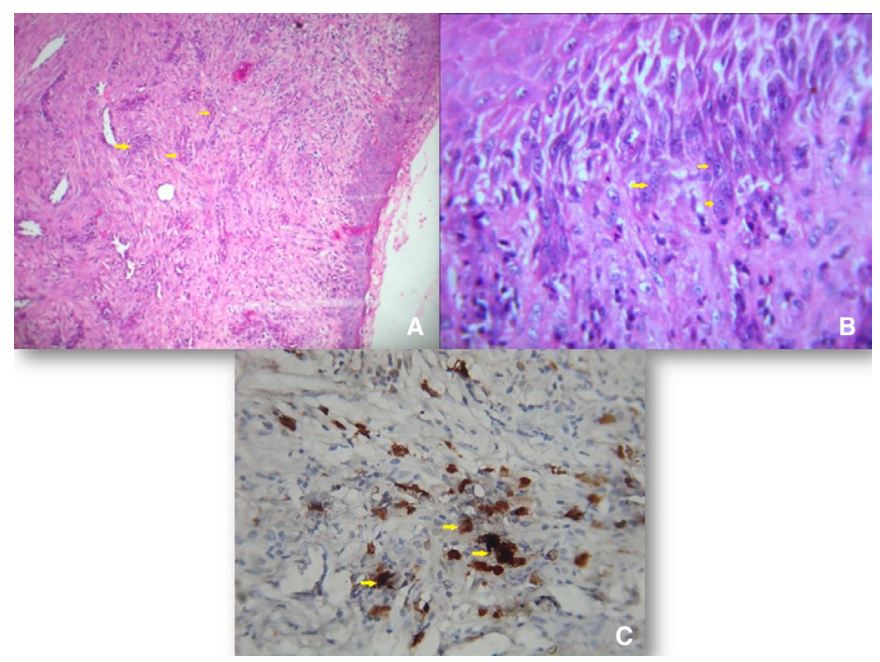

Figure 3 The H\&E-stained section showing atypical melanocytes along the basilar layer of the overlying epithelium with widely scattered, non-pigmented spindle as well as round cells possessing moderately enlarged nuclei with coarse chromatin pattern in the connective tissue. (A) Original magnification 10x; (B) 40x and (C) atypical junctional melanocytes, spindle and round cells in the connective tissue were strongly positive for S-100.

single dispersion along the basilar layer of the overlying epithelium (figure 3A). In addition, widely scattered, non-pigmented spindle as well as round cells possessing moderately enlarged nuclei with coarse chromatin pattern were identified in the connective tissue (figure 3B). Atypical junctional melanocytes, spindle and round cells in the connective tissue were strongly positive for S-100 (figure 3C). The case was diagnosed as MM and the patient was advised for surgery but he passed away within 3 months.

Primary oral MM is extremely rare accounting for about $0.2 \%-8 \%$ of all MMs. It is seen in the elders aged $>60$ years, clearly exhibiting a male gender predilection. ${ }^{4} \mathrm{MM}$ usually arises from the epidermal melanocytes de novo and the hard palate and the maxillary gingiva are the most common intraoral sites as observed in this case as well. MM poses a diagnostic challenge as there are no pathognomonic clinical features. Hence, an asymptomatic blackish-brown pigmented patch needs to be excised due to its tendency of rapid metastasis.

Surgical resection is the most preferred treatment modality for oral MM. Though once considered resistant to radiotherapy, adjuvant therapy involves the use of radiation for local control. ${ }^{5}$ Chemotherapy and immunotherapy are other adjuvant therapies which are being used recently with favourable results. ${ }^{6}$ The prognosis is extremely poor with a 5 -year survival rate $<30 \%$ which is attributed to diagnostic delays and distant metastasis. In this case also, the patient delayed undergoing surgery and passed away within 3 months of diagnosis.

$\mathrm{MM}$ of the oral cavity is not only rare but also lethal. An oral physician is the most likely person to observe and diagnose this rapidly progressive lesion early and save lives. Therefore, it is imperative to increase awareness among dentists, regarding considering $\mathrm{MM}$ in the differential diagnosis of asymptomatic irregular melanotic lesions.

\section{Learning points}

- Malignant melanoma is an exceedingly rare oral malignancy which is extremely aggressive and a rapidly spreading tumour.

- The clinical presentation may be misleading due to the asymptomatic nature of the lesion and needs to be investigated thoroughly.

- Early diagnosis and prompt treatment could be lifesaving as the prognosis is very poor.

Contributors SRM and URT examined, investigated the patient and prepared the manuscript. NM performed the histopathologic evaluation. RD performed the literature search.

Funding The authors have not declared a specific grant for this research from any funding agency in the public, commercial or not-for-profit sectors.

Competing interests None declared.

Patient consent for publication Consent obtained from next of kin.

Provenance and peer review Not commissioned; externally peer reviewed.

\section{REFERENCES}

1 Rani GS, Kumar TV, Kolasani B, et al. Primary malignant melanoma of maxilla: report of a case with discussion. Case Rep Dent 2014;2014:624306 doi:10.1155/2014/624306

2 Devi S, Sinha R, Singh RK. Malignant melanoma maxilla. Natl J Maxillofac Surg 2015;6:115-8.

3 Lin C-W, Lee Y-P, Hwang M-J, et al. Oral mucosal melanoma: case report. J Dent SCi 2020:15:556-7.

4 Ashok S, Damera S, Ganesh S, et al. Oral malignant melanoma. J Oral Maxillofac Pathol 2020:24:82-5.

5 Pradhan P, Adhya AK. Extensive malignant melanoma of the oral cavity: a rare occurrence. Autops Case Rep 2021;11:e2021299.

6 Chandan SN, Shetty SK, Deepa BV. Primary Malignant Melanoma of Oral Mucosa Report of Two Cases. Contemp Clin Dent 2020;11:195-8.

Copyright 2021 BMJ Publishing Group. All rights reserved. For permission to reuse any of this content visit

https://www.bmj.com/company/products-services/rights-and-licensing/permissions/

BMJ Case Report Fellows may re-use this article for personal use and teaching without any further permission.

Become a Fellow of BMJ Case Reports today and you can:

- Submit as many cases as you like

- Enjoy fast sympathetic peer review and rapid publication of accepted articles

- Access all the published articles

- Re-use any of the published material for personal use and teaching without further permission

Customer Service

If you have any further queries about your subscription, please contact our customer services team on +44 (0) 2071111105 or via email at support@bmj.com.

Visit casereports.bmj.com for more articles like this and to become a Fellow 